\section{Original Article}

\title{
Influence of Intramasseteric Injection of Botulinum Toxin Type A on the Ipsilateral Submandibular Salivary Gland of Albino Rats
}

\author{
Safaa Ismail Hussein
}

\author{
Oral Biology Department, Faculty of Dentistry, Ain Shams University, Cairo, Egypt
}

\begin{abstract}
Background: Botulinum toxins are used in treating involuntary muscle contraction such as hemifacial spasm and facial nerve palsy, hyperhidrosis or excessive saliva production. Minor side effects are reported like local hematoma, pain, dry mouth and viscous saliva. However; major complications may occur such as loss of motor head control and aspiration pneumonia. Some animal studies showed minimal histological changes. While, some authors have demonstrated significant structural and functional changes in the parotid gland of rats and the submandibular gland of rabbits after being injected with botulinum toxin type-A (BTX-A).

Aim of the Study: To evaluate the effect of intramasseteric injection of BTX-A on the ipsilateral submandibular gland in Albino rats.

Materials and Methods: Fifty six adult male Albino rats were divided into four groups. Rats of group (I) and group (II) received intramasseteric injection of $0.05 \mathrm{ml}$ or $0.1 \mathrm{ml}$ of $0.9 \%$ sodium chloride solution respectively. Rats of group (III) and group (IV) received intra-masseteric injection of 2.5 units or 5 units of BTX-A respectively. Each group was further subdivided into two subgroups according to the time of sacrifice which was at three or fourteen days. Sections of glands were stained by H\&E and S100 protein antibody.

Results: Glands' acini of group III and IV showed cytoplasmic vacuolations. Acini of group IV at fourteen days showed irregular outline with areas of complete degeneration. Duct system of both groups showed signs of degeneration.

Using immunohistochemical staining, group III and IV showed increased area percentage of positive reaction than control groups. Statistical analysis of acini diameter and area percentage of anti-S100 protein revealed significant increase in botox injected subgroups.

Conclusion: Intramasseteric injection with BTX-A was able to induce histological changes in submandibular gland of the ipsilateral side.
\end{abstract}

Received: 10 December 2019, Accepted: 01 January 2020

Key Words: Botulinum toxin; intramasseteric; ipsilateral; submandibular gland.

Corresponding Author: Safaa Ismail Hussein, PhD, Oral Biology Department, Faculty of Dentistry, Ain Shams University, Egypt, Tel.: +20 1112235569, E-mail: safaaismai155@gmail.com

ISSN: 1110-0559, Vol. 43, No.3

\section{INTRODUCTION}

Botulinum toxins (BTX) are neurotoxic proteins produced by Clostridium Botulinum, an anaerobic bacterium. BTX exist in seven different types which are A, B, C, D, E, F and $\mathrm{G}^{[1,2]}$. Felber, 2006 $6^{[3]}$ described the biochemistry and mechanism of action of BTX as a single-chain protein that is inactive until cleaved by its own proteases into a heavy and a light chain. Where, the active heavy chain mediates the binding to the presynaptic cholinergic neuromuscular end plate. Membrane-embedded proteins named synaptosomal-associated proteins (SNAPs) are responsible for the release of acetylcholine (ACh). The light chain of BTX type A (BTX-A) cleaves SNAP-25 thus preventing the release of $\mathrm{ACh}$ into the neuromuscular junction. Re-innervation restores muscle activity in about three months.

Despite its toxicity, BTX is used in the treatment of numerous medical disorders such as, involuntary muscle contraction, hyperhidrosis or excessive saliva production as well as having well-known use in cosmetic industry ${ }^{[1,4]}$.

The application of BTX-A (also known as Botox) as a treatment for sialorrhea was first proposed in 1997 through intra-glandular injection. Where, it acts by inhibiting $\mathrm{ACh}$ release at the presynaptic level through acting on cholinergic (parasympathetic) nerve terminals causing local chemical blocking and loss of neuronal activity in the target organ ${ }^{[5]}$. The intra-glandular injection of BTX-A or B has been used to treat hypersalivation because it is able to depress the secretory action of salivary glands thus saliva production can be effectively reduced ${ }^{[6-8]}$. Thus, BTX has been proposed as a treatment for sialorrhea which may complicate some neurological diseases ${ }^{[9]}$.

So the aim of this study was to evaluate the possible effect of intramasseteric injection of BTX-A on the histology of ipsilateral submandibular salivary glands in Albino rats. 


\section{MATERIALS AND METHODS}

\section{Animals}

Fifty six adult male Albino rats weighing between 200250 grams were used in this study. The rats were housed in the Animal House of "The Medical Research Center" in Ain Shams University. Rats were kept under good ventilation and adequate stable diet consisting of fresh vegetables, dried bread and tap water throughout the experimental period. This was reviewed and approved by the ethics committee of Faculty of Dentistry, Ain Shams University, Cairo, Egypt (final approval number is (FDASU-RECIR 091905) and performed in accordance with the guide for care and use of laboratory animals ${ }^{[10]}$.

\section{Experimental groups}

After one week of accommodation, the rats were randomly divided into four equal groups (fourteen rats each):

I) Control group (group I): rats received single intramasseteric injection of $0.05 \mathrm{ml} 0.9 \%$ sodium chloride solution (Almottahedoon Pharma).

II) Control group (group II): rats received single intramasseteric injection of $0.1 \mathrm{ml} 0.9 \%$ sodium chloride solution.

III) Botox group (group III): rats received a single dose of intra-masseteric injection of 2.5 units BTX-A "Neuronox ${ }^{\circledR}$ " made by Medytox, Korea. The BTX-A powder was dissolved in $0.05 \mathrm{ml} 0.9 \%$ sodium chloride solution $^{[11]}$.

IV) Botox group (group IV): rats received a single dose of intra-masseteric injection of 5 units of BTX-A. The BTX-A powder was dissolved in $0.1 \mathrm{ml} 0.9 \%$ sodium chloride solution $^{[12]}$.

In all groups the injection was done into the right masseter muscle. Each group was further subdivided into two equal subgroups (seven rats each) according to the time of sacrifice which was at three or fourteen days after injection. The subgroups of each group were named A and $\mathrm{B}$ respectively.

\section{Samples preparation}

At the end of the experiment, rats were sacrificed separately by overdose of anesthesia and dissected to obtain the submandibular salivary glands. The specimens were fixed immediately in $10 \%$ formalin solution and then washed under running tap water to remove all fixative residues. Specimens were then dehydrated by being transferred in increasing concentrations of alcohol and then cleared by xylol. The dehydrated samples were then embedded in the center of paraffin wax blocks to be sectioned by microtome to a thickness of four to five microns. Sections were transferred in decreasing concentrations of alcohol and then distilled water to be stained by:
1. Hematoxylin and Eosin (H\&E) stains: for routine histological examination ${ }^{[13]}$.

2. Immunohistochemical staining using anti-S100 protein antibody: Endogenous peroxidase activity was inhibited by 3\% hydrogen peroxide (88597) (Sigma-Aldrich, St. Louis, MO, USA) in distilled water for $5 \mathrm{~min}$, and then the sections were washed in Tris buffered saline (T 5030-100 TAB, $\mathrm{pH}$ 7.6) (Sigma-Aldrich, St. Louis, MO, USA) twice ( $5 \mathrm{~min}$ for each). Non-specific binding to antibodies was blocked by incubation with protein block (RE7102) (Novocastra) for $5 \mathrm{~min}$. Sections were incubated with anti-S100 antibody (mouse monoclonal, with dilution 1:500) (Santa Cruz Biotechnology, Dallas, Texas, USA, S-100 (S1-61): sc-53438) for 1 hour at room temperature. Sections were then washed in Tris buffer for 3 times (each for $3 \mathrm{~min}$ ) and then incubated with biotinylated secondary antibody (RE7103) (Novocastra) for $30 \mathrm{~min}$. Then slides were washed 3 times in Tris buffer (each for $3 \mathrm{~min}$ ) and incubated with Novolink polymer (RE7280CE) (Novocastra) for $30 \mathrm{~min}$. Sections were then washed 3 times in Tris buffer (each for $3 \mathrm{~min}$ ). Peroxidase was detected with diaminobenzidine substrate (RE7106) (Novocastra) for $10 \mathrm{~min}$. Sections were washed in distilled water for 10 min. Finally, slides were counterstained with hematoxylin (H3136) (Sigma-Aldrich, St. Louis, MO, USA $)^{[14]}$.

\section{Histomorphometric analysis}

Examination of both $\mathrm{H} \& \mathrm{E}$ and anti S-100 protein stained sections was done using a light microscope (Model BX40F4, 7E12569) Olympus Optical Co., LTD. Japan. Photographing was done using a mounted camera (Olympus soft imaging solutions, Munster, Germany, Model LC20, 59001227). This was done at Oral Biology Department, Faculty of Dentistry, Ain Shams University, Cairo, Egypt.

H\&E and anti S-100 protein stained sections (magnification 400X) were randomly selected. Diameter of acini in H\&E stained sections were measured from five acini from each sample with a total of thirty five acini in each subgroup. Positively stained areas in anti S-100 protein stained sections were analyzed from five microscopic fields in each sample. Computerized calculation of the total positively stained surface area was expressed as a percentage of the total surface area of the microscopic field using image $\mathrm{j}$ software.

\section{Statistical Analysis}

Recorded data were analyzed using the statistical package for social sciences, version 20.0 (SPSS Inc., Chicago, Illinois, USA). Quantitative data were expressed as mean \pm standard deviation (SD). One-way analysis of variance (ANOVA) was used, followed by Post Hoc test for multiple comparisons between different variables. 


\section{RESULTS}

\section{1- Light microscopic results for $H \& E$ stained sections}

Submandibular glands of the group I and II revealed normal glandular structure. The glands of the subgroups IA and IIA were shown as examples of the control groups. The acini were lined by pyramidal cells with basophilic cytoplasm and basal rounded nuclei. Intercalated ducts (IDs) were lined by cuboidal cells with rounded nuclei. Granular convoluted tubules (GCTs) were lined by columnar cells with acidophilic cytoplasm and basal rounded nuclei (Figures 1A and 1D). Striated ducts (SDs) were lined by columnar cells with acidophilic cytoplasm and rounded nuclei and were surrounded by normal sized blood vessels (Figures 1B and 1E). Excretory ducts (EDs) were lined by pseudostratified columnar epithelium with goblet cells (Figures 1C and 1F).

Submandibular glands of subgroup IIIA showed few cytoplasmic vacuolations in acini. SD appeared almost normal except for some stagnant secretion in its lumen (Figure 2A). ID cells appeared flattened. GCTs showed decrease in the acidophilic appearance of the cytoplasm (Figure 2B). Focal degeneration was seen in ED (Figure2C).

In subgroup IIIB, acini and SD cells showed cytoplasmic vacuolations. GCT showed decreased acidophilic appearance of the cytoplasm (Figure 2D). ID revealed flattened cells. Desquamated cells and increased spacing were observed between acini at some regions (Figure 2E). Focal degeneration in ED was detected with desquamated cells in its lumen (Figure 2F).

Glands of subgroup IVA presented cytoplasmic vacuolations in acini; desquamated cells and increased spacing between acini. ID appeared with flattened cell lining. SD exhibited focal degeneration and some stagnant secretion in the lumen. GCT presented degeneration with loss of cellular outline (Figure 3A). ED showed flattening in its lining and the duct was surrounded by normal blood vessels (Figure 3B).

Acini of subgroup IVB displayed irregular outline with areas of complete degeneration. Desquamated cells and increased spacing were seen between acini. Degeneration was detected in GCT (Figure 3C). ID showed decreased number of nuclei in some areas. SD presented focal degeneration (Figure 3D). Stagnant secretion was found in ED lumen and the duct was surrounded by normal blood vessel (Figure 3E).

\section{2-Lightmicroscopicresultsforimmunohistochemical anti-S100 protein stained sections}

Submandibular glands of both control groups were similar to each other. Subgroups IA and IIA were shown as examples. Most of SDs were almost negative to anti-S100 protein except for very few localized areas of positive reaction that was mostly nuclear (Figures 4A and 4D). Few positive nuclear and cytoplasmic areas were detected in GCTs (Figures 4B and 4D). Few localized areas of positive reaction were seen surrounding the acini (Figures $4 \mathrm{~B}$ and 4E). The EDs showed almost negative reaction except for very few localized areas of positive nuclear reaction and diffuse reaction surrounding the ducts (Figures 4Cand 4F).

Glands of subgroup IIIA and IIIB showed few localized areas of positive reaction surrounding the acini. Few localized areas of positive nuclear and cytoplasmic areas were detected in both SDs and GCTs (Figures 5A and $5 \mathrm{C})$. Few localized areas of positive nuclear reaction were detected in EDs with diffuse reaction surrounding the ducts (Figures 5B and 5D).

In subgroup IVA few localized areas of positive reaction were detected surrounding the acini (Figure 6A), while in subgroup IVB the positive areas surrounding acini appeared to be increased (Figure 6D).

In both subgroups IVA and IVB, diffuse nuclear and cytoplasmic reactions were found in SDs and GCTs (Figures 6A, 6C and 6D). The EDs revealed few localized areas of positive nuclear and cytoplasmic reaction and diffuse reaction surrounding the ducts (Figures 6B and 6E).

\section{3-Statistical results}

\section{A) Diameter of acini}

Using one way Anova test, there were significant differences between subgroups. Post-hoc test showed significant difference between subgroups IIIA, IIIB, IVA and IVB when compared to the control subgroups. Where the diameter of acini was significantly increased in the botox injected groups. Subgroup IVB also showed a significant increase in the diameter when compared to other botox injected subgroups (Table 1 and Figure 7).

\section{B) Area percentage of anti-S100 protein}

One way Anova test, revealed significant differences between subgroups. Post-hoc test showed significant difference between subgroups IIIA, IIIB, IVA and IVB when compared to the control subgroups. Where area percentage of anti-S100 protein was significantly increased in botox injected subgroups. Area percentage was also significantly increased in subgroup IVA when compared to subgroup IIIA. Subgroup IVB also showed a significant increase in the area percentage of anti-S100 protein when compared to other botox injected subgroups (Table 2 and Figure 8). 

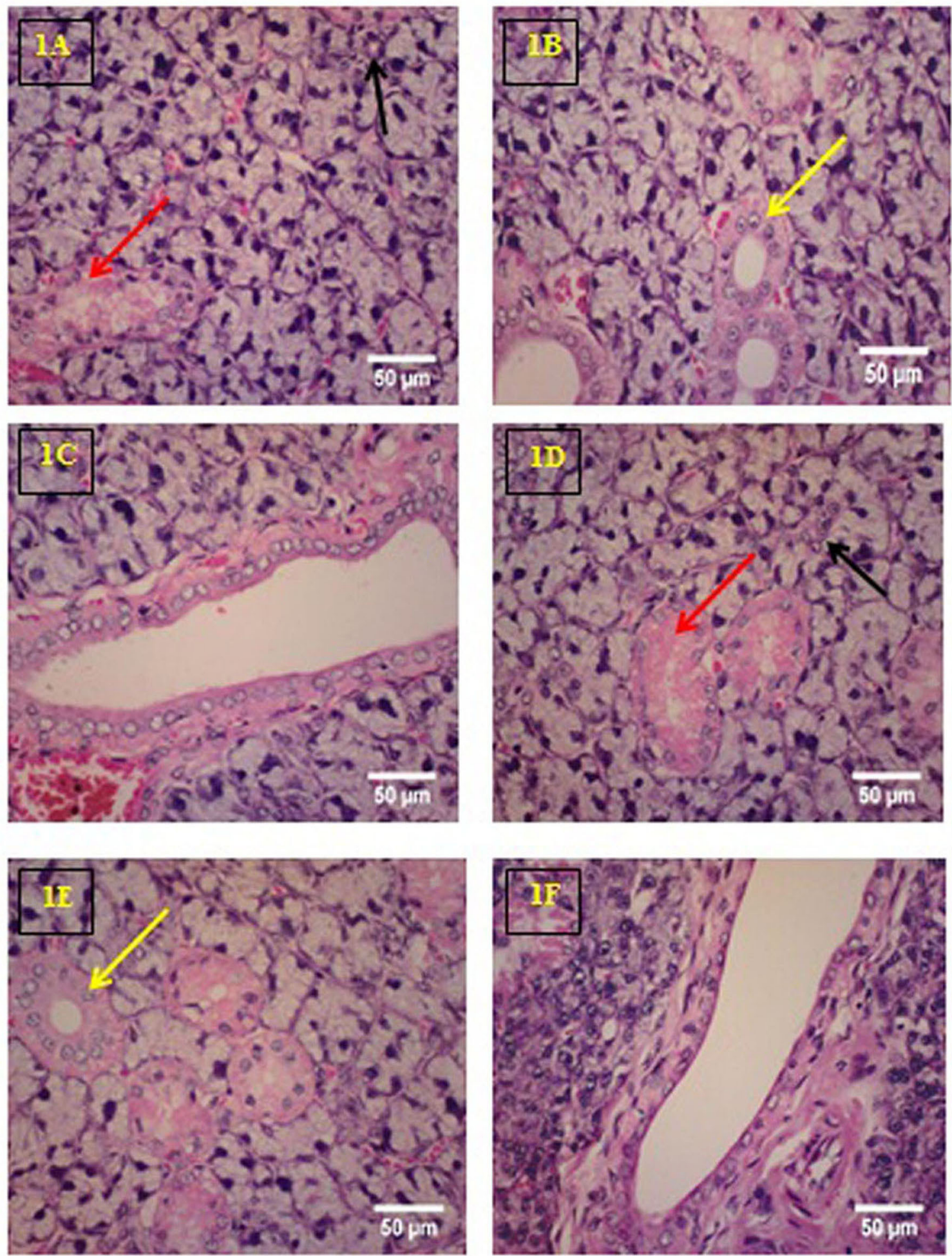

Fig. 1: A: Submandibular gland of subgroup IA showing normal acini, ID (black arrow) and GCT (red arrow).

B: Normal SD (yellow arrow) surrounded by normal sized blood vessel.

C: Normal lining of ED.

D: Submandibular gland of subgroup IIA showing normal acini, ID (black arrow) and GCT (red arrow).

E: Normal SD (yellow arrow) surrounded by normal sized blood vessel.

F: Normal lining of ED (H \& E x400). 

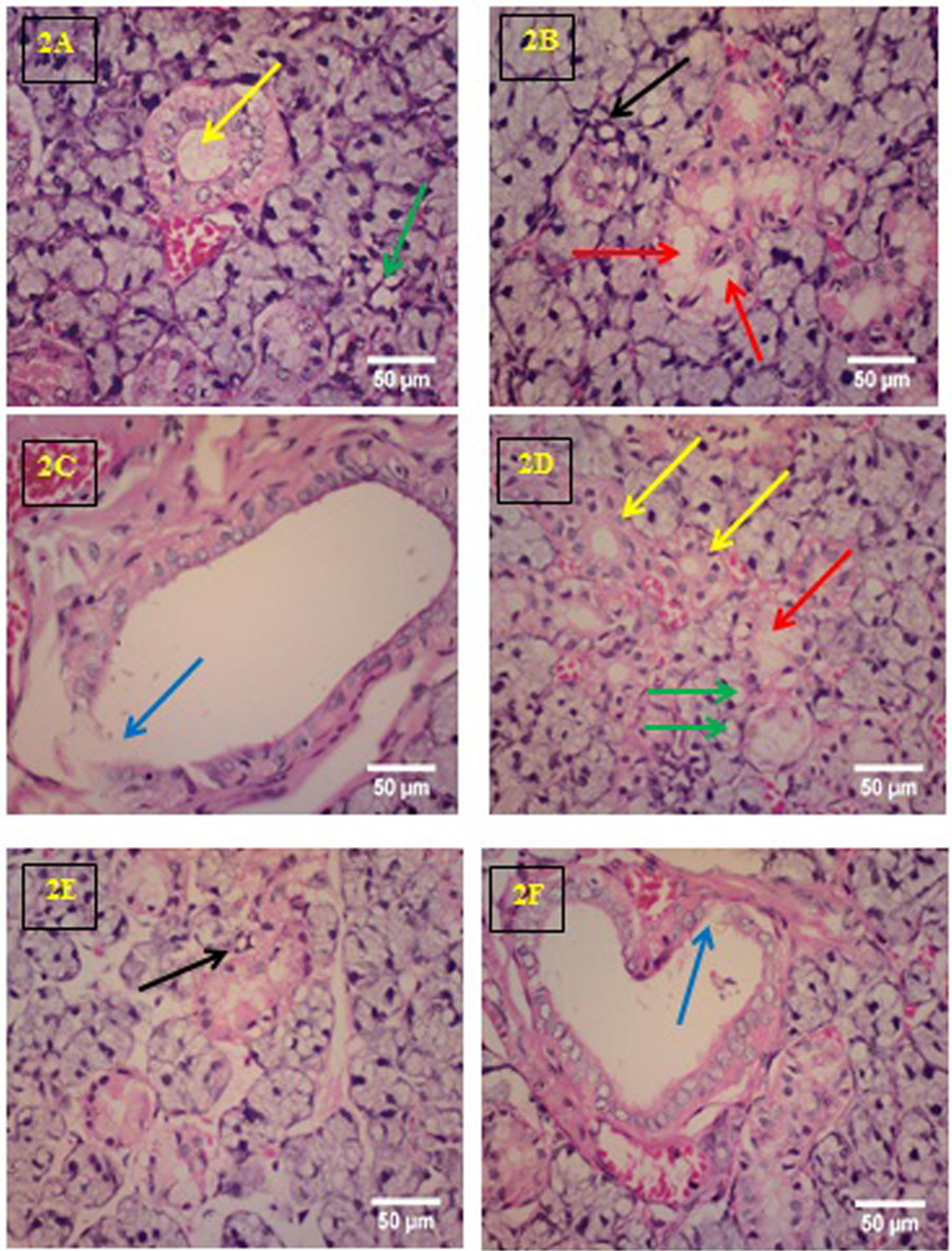

Fig. 2: A: Submandibular gland of subgroup IIIA showing few cytoplasmic vacuolations in acini (green arrow), SD is almost normal except for some stagnant secretion in its lumen (yellow arrow).

B: ID appears with decreased cellular height (black arrow). GCT shows decreased acidophilic appearance of the cytoplasm (red arrows).

C: Focal degeneration in ED (blue arrow).

D: Submandibular gland of subgroup IIIB showing cytoplasmic vacuolations in acini (green arrows). SD shows vacuolations in its lining (yellow arrows). GCT shows decreased acidophilic appearance of the cytoplasm (red arrow).

E: ID appears with decreased cellular height (black arrow). Desquamated cells and increased spacing between acini.

F: Focal degeneration in ED (blue arrow) with desquamated cells in the lumen (H \& E x 400). 

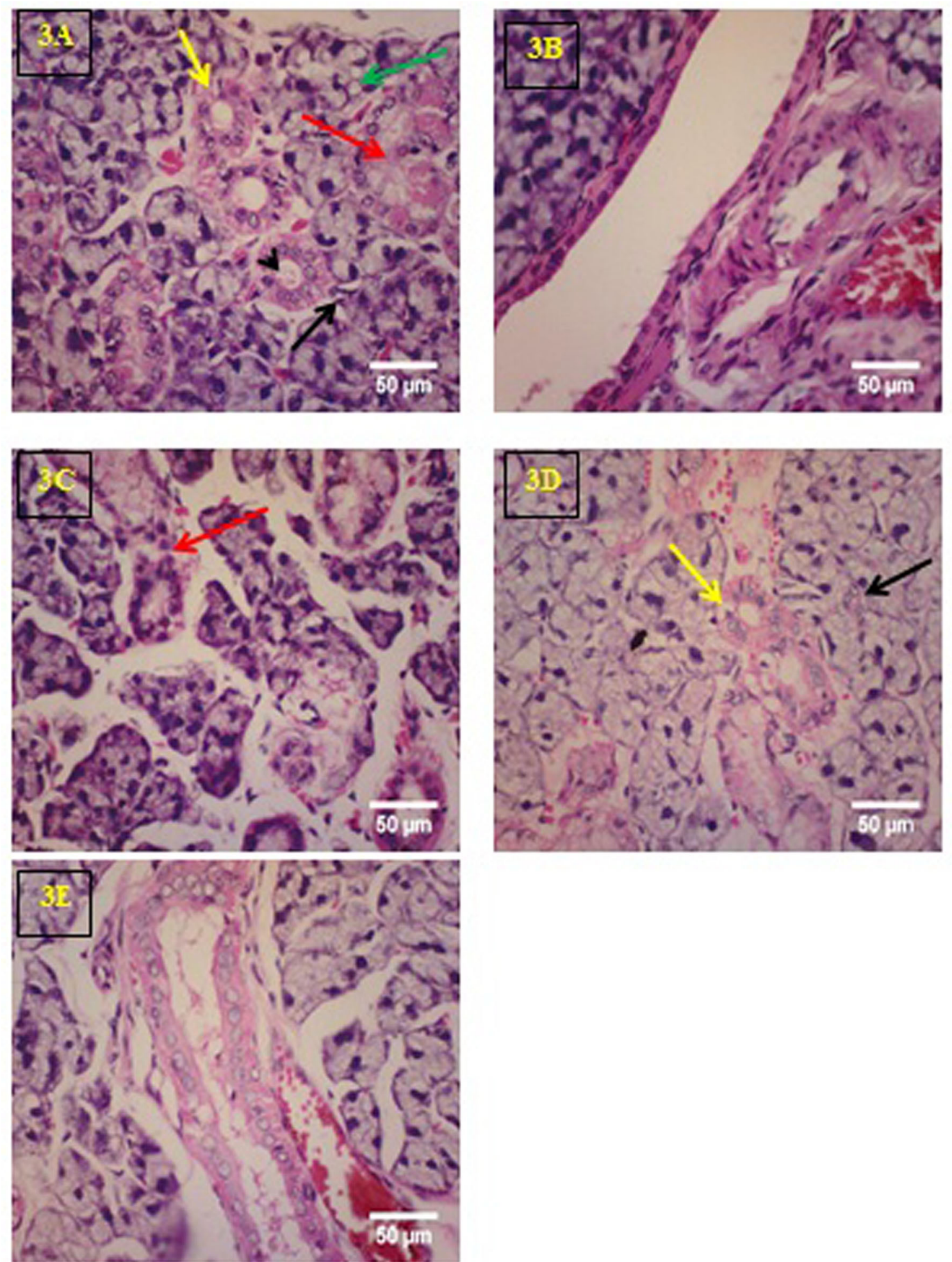

Fig. 3: A: Submandibular gland of subgroup IVA showing cytoplasmic vacuolations in acini (green arrow), desquamated cells and increased spacing. ID appears with decreased cellular height (black arrow). SD shows focal degeneration (yellow arrow) and some stagnant secretion in the lumen (arrow head). GCT shows degeneration with loss of cellular outline (red arrow).

B: Flattening in ED lining and the duct is surrounded by normal blood vessels.

C: Submandibular gland of subgroup IVB showing irregular outline of acini with areas of complete degeneration, desquamated cells and increased spacing between acini. GCT shows degeneration (red arrow).

D: ID with decreased number of nuclei (black arrow). SD shows focal degeneration (yellow arrow).

E: Stagnant secretion in ED lumen and the duct is surrounded by normal blood vessel (H \& E x 400). 

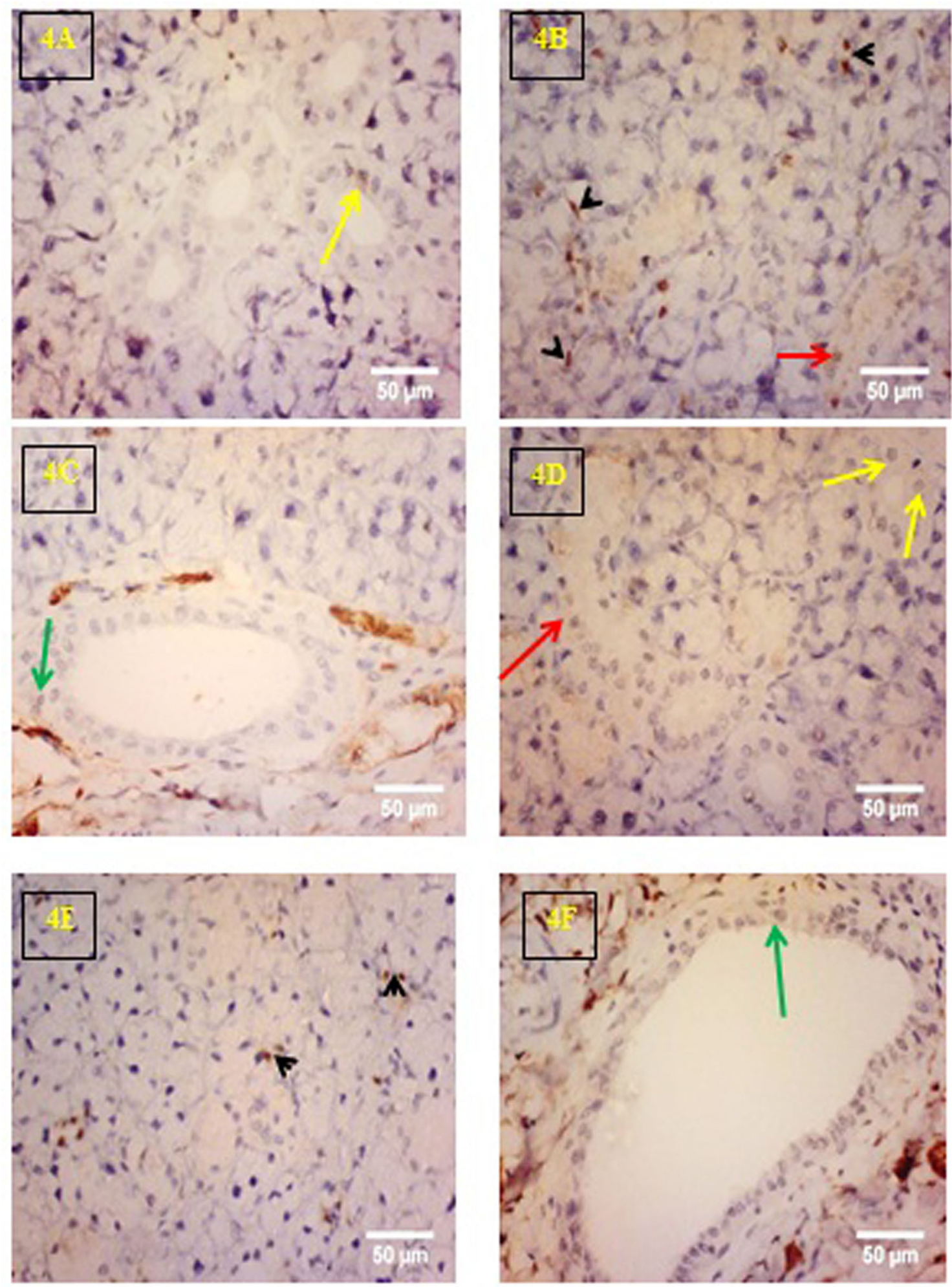

Fig. 4: A: Submandibular gland of subgroup IA showing SD almost negative with very few localized areas of positive reaction (yellow arrow). B: Few localized areas of positive nuclear reaction surrounding the acini (arrow heads) and in GCT (red arrow) with few cytoplasmic areas in GCT. C: ED almost negative with very few localized areas of positive nuclear reaction (green arrow) and diffuse reaction surrounding the duct.

D: Submandibular gland of subgroup IIA showing SD almost negative with very few localized areas of positive reaction (yellow arrows) GCT (red arrow) with few nuclear and cytoplasmic positive areas.

E: Few localized areas of positive nuclear reaction surrounding the acini (arrow heads).

F: ED almost negative with very few localized areas of positive nuclear reaction (green arrow) and diffuse reaction surrounding the duct (anti S100 protein $\mathrm{x} 400)$. 

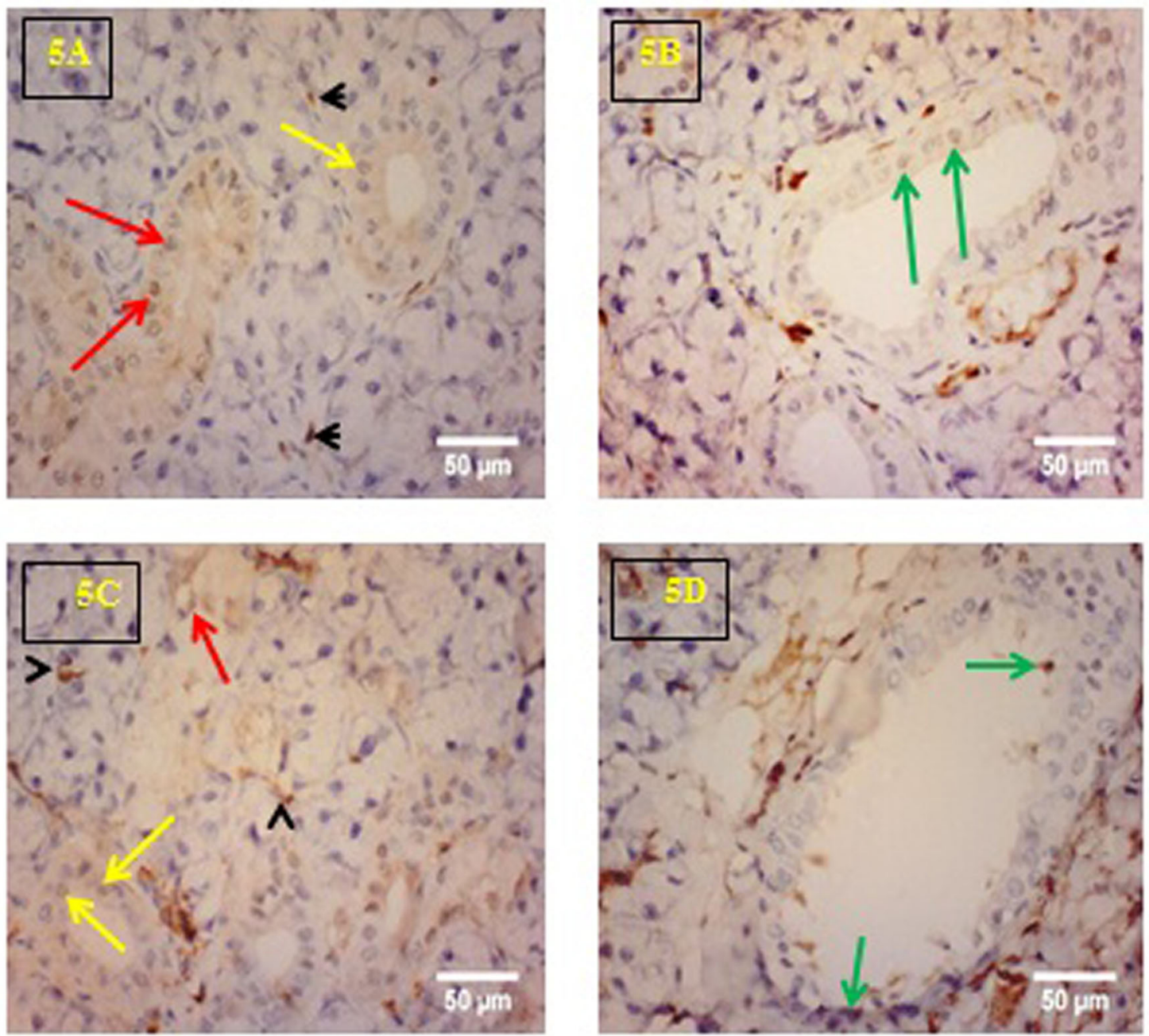

Fig. 5: A: Submandibular gland of subgroup IIIA showing few localized areas of positive nuclear reaction surrounding the acini (arrow heads), in SD (yellow arrow) and in GCT (red arrows) with cytoplasmic areas in SD and GCT.

B: Few localized areas of positive nuclear reaction in ED (green arrows) and diffuse reaction surrounding the duct.

C: Submandibular gland of subgroup IIIB showing few localized areas of positive nuclear reaction surrounding the acini (arrow heads), in SD (yellow arrows) and in GCT (red arrow) with cytoplasmic areas in SD and GCT.

D: Few localized areas of positive nuclear reaction in ED (green arrow) and diffuse reaction surrounding the duct (anti S100 protein $\mathrm{x} 400$ ). 

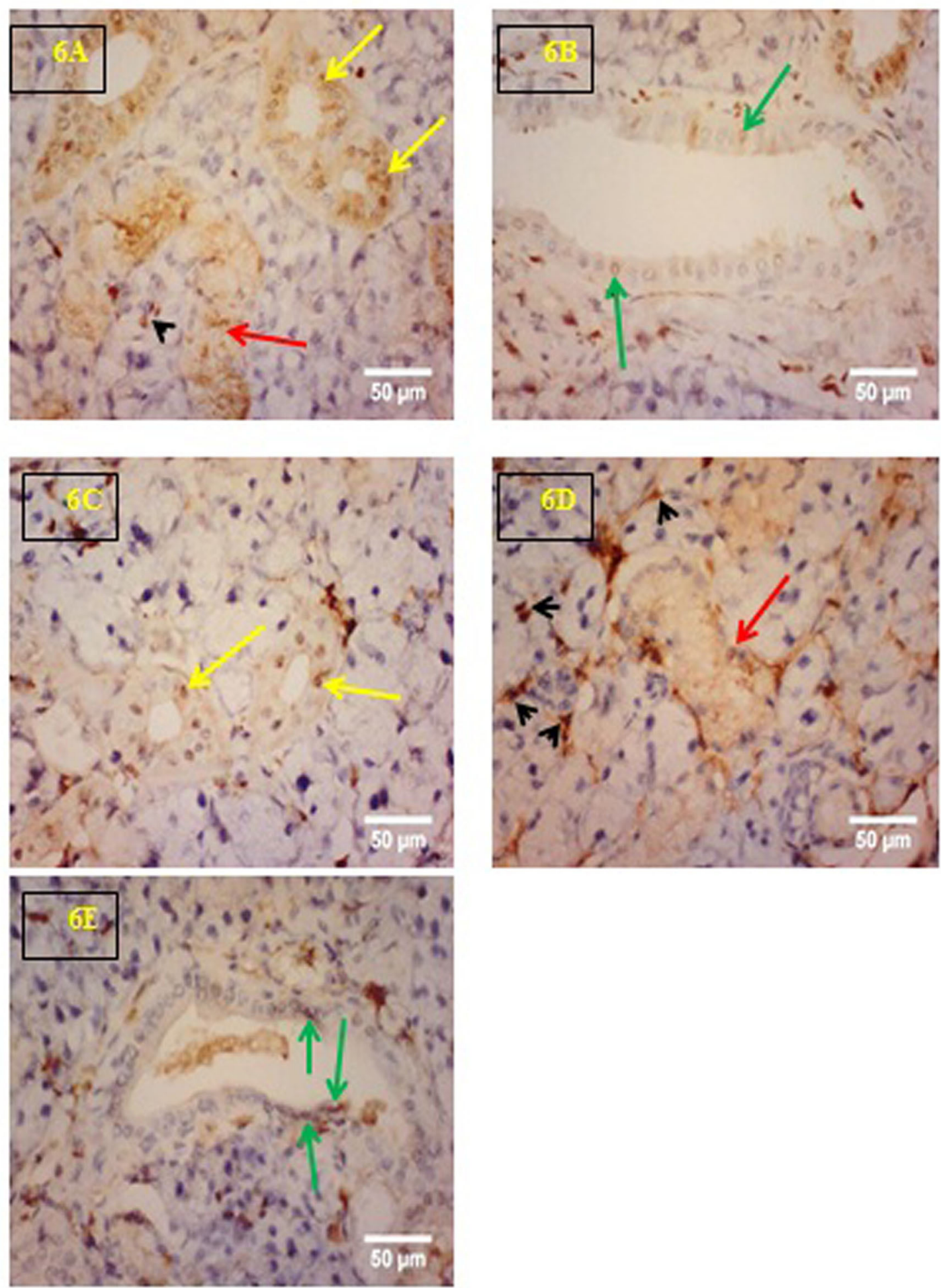

Fig. 6: A: Submandibular gland of subgroup IVA showing few localized areas of positive nuclear reaction surrounding the acini (arrow head), diffuse nuclear and cytoplasmic reactions in SDs (yellow arrows) and GCT (red arrow).

B: Few localized areas of positive nuclear and cytoplasmic reactions in ED (green arrows) and diffuse reaction surrounding the duct.

C: Submandibular gland of subgroup IV B showing diffuse nuclear and cytoplasmic reactions in SD (yellow arrows).

D: Localized areas of positive nuclear reaction surrounding the acini (arrow heads), diffuse nuclear (red arrow) and cytoplasmic reaction in GCT.

E: Few localized areas of positive nuclear and cytoplasmic reactions in ED (green arrows) and diffuse reaction surrounding the duct (anti S100 protein $\mathrm{x} 400$ ). 


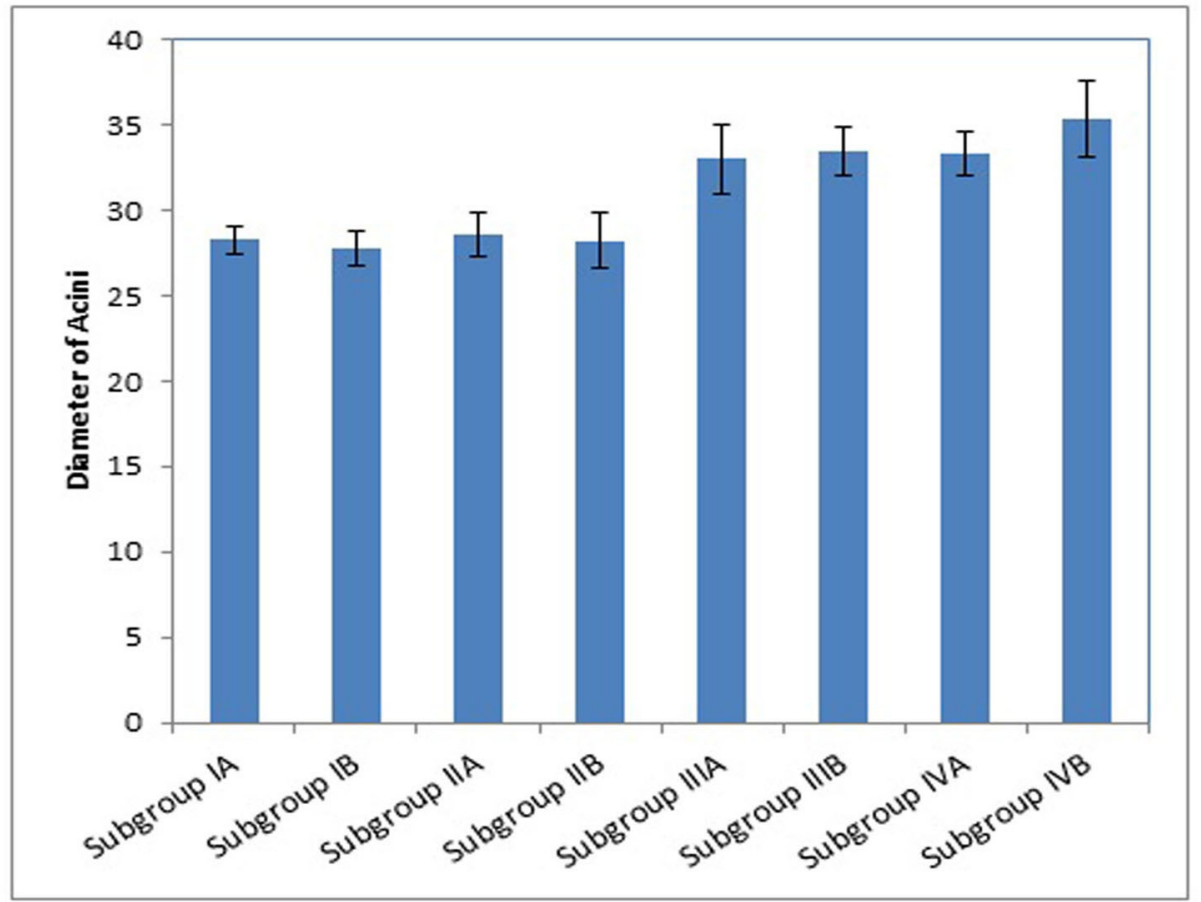

Fig. 7: Comparison between sub-groups according to diameter of acini.

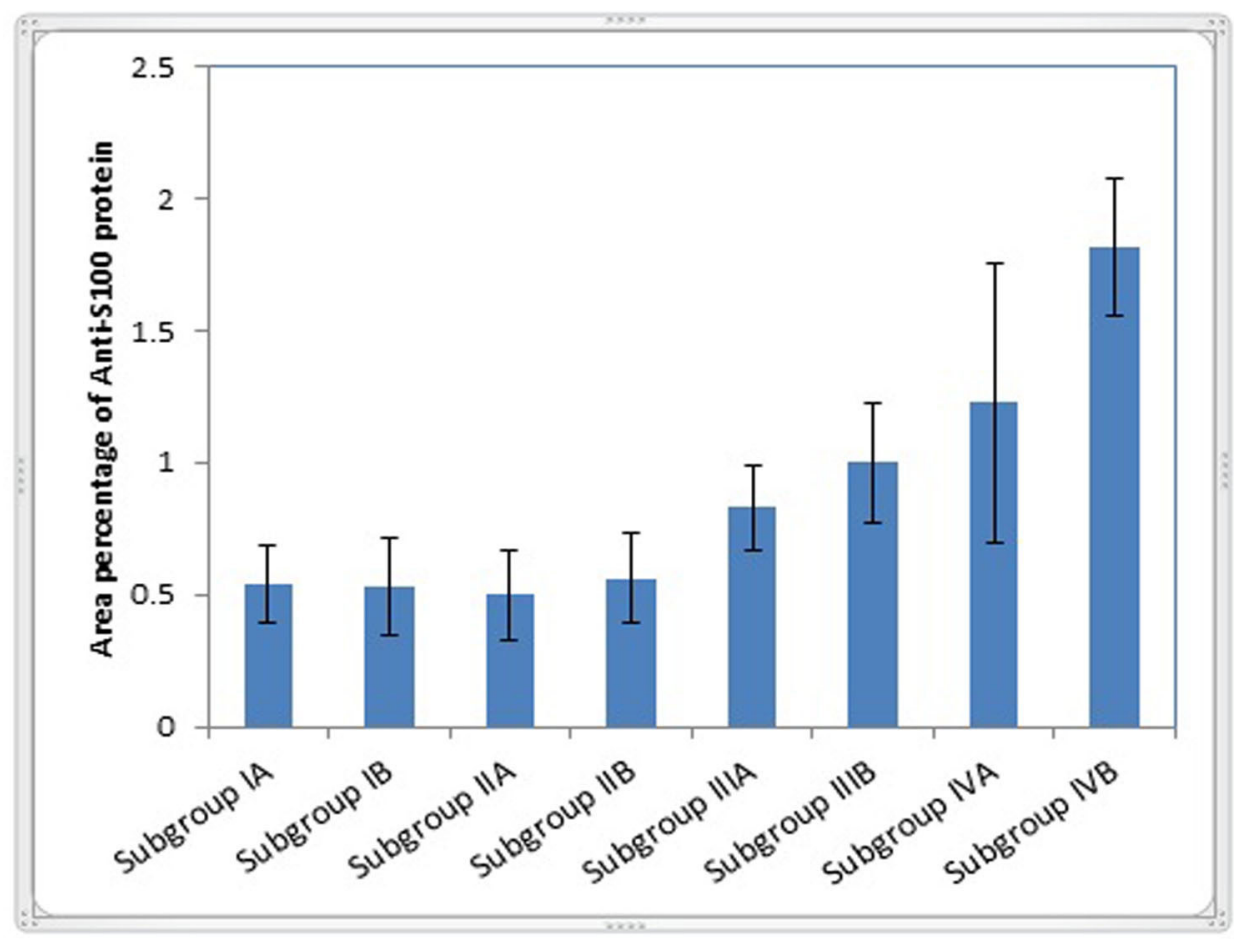

Fig. 8: Comparison between sub-groups according to area percentage of anti-S100 protein. 
Table 1: Comparison between sub-groups according to diameter of acini

\begin{tabular}{lcc}
\hline \multirow{2}{*}{ Groups } & \multicolumn{2}{c}{ Diameter of Acini } \\
\cline { 2 - 3 } & Mean \pm SD & Range \\
\hline Subgroup IA & $28.31 \pm 0.81$ & $27.3-29.6$ \\
Subgroup IB & $27.80 \pm 1.01$ & $26.5-29.5$ \\
Subgroup IIA & $28.54 \pm 1.29$ & $27.1-30.6$ \\
Subgroup IIB & $28.24 \pm 1.61$ & $26.0-31.0$ \\
Subgroup IIIA & $33.00 \pm 2.00^{\text {abcd }}$ & $29.1-35.0$ \\
Subgroup IIIB & $33.51 \pm 1.43^{\text {abcd }}$ & $30.6-35.2$ \\
Subgroup IVA & $33.29 \pm 1.30^{\text {abcd }}$ & $32.0-35.0$ \\
Subgroup IVB & $35.33 \pm 2.25^{\text {abcdefg }}$ \\
ANOVA test & \multicolumn{2}{c}{27.940} \\
$p$-value & \multicolumn{2}{c}{$<0.001^{* *}$} \\
\hline
\end{tabular}

Using: ANOVA: ${ }^{* *}$-value $<0.001$ Highly Significant

Using Post-hoc:

a: significant difference with subgroup IA; b: significant difference with subgroup IB

c: significant difference with subgroup IIA; d: significant difference with subgroup IIB

e: significant difference with subgroup IIIA; f: significant difference with subgroup IIIB

g: significant difference with subgroup IVA

Table 2: Comparison between subgroups according to area percentage of anti-S100 protein

\begin{tabular}{lcc}
\hline \multirow{2}{*}{ Groups } & \multicolumn{2}{c}{ Area percentage of Anti-S100 protein } \\
\cline { 2 - 3 } & Mean \pm SD & Range \\
\hline Subgroup IA & $0.54 \pm 0.15$ & $0.3-0.7$ \\
Subgroup IB & $0.53 \pm 0.18$ & $0.3-0.8$ \\
Subgroup IIA & $0.50 \pm 0.17$ & $0.3-0.7$ \\
Subgroup IIB & $0.56 \pm 0.17$ & $0.3-0.8$ \\
Subgroup IIIA & $0.83 \pm 0.16^{\text {abcd }}$ & $0.6-1.1$ \\
Subgroup IIIB & $1.00 \pm 0.23^{\text {abcd }}$ & $0.7-1.3$ \\
Subgroup IVA & $1.23 \pm 0.53^{\text {abcde }}$ & $0.6-2.1$ \\
Subgroup IVB & $1.82 \pm 0.26^{\text {abcdefg }}$ & $1.5-2.2$ \\
ANOVA test & \multicolumn{2}{c}{22.172} \\
$p$-value & $<0.001^{* *}$ \\
\hline
\end{tabular}

Using: ANOVA: $* *$-value $<0.001$ Highly Significant

Using Post-hoc:

a: significant difference with subgroup IA; b: significant difference with subgroup IB

c: significant difference with subgroup IIA; d: significant difference with subgroup IIB

e: significant difference with subgroup IIIA; f: significant difference with subgroup IIIB

g: significant difference with subgroup IVA

\section{DISCUSSION}

The therapeutic use of BTX has been reviewed by Felber, $2006^{[3]}$ as a treatment for allergic rhinitis, migraine, myofascial pain syndrome, focal dystonia of the hand, and cosmetic facial improvement such as brow lift, glabellar furrows, lateral canthal lines and transverse forehead lines. BTX is commonly used to reduce signs of aging (facial wrinkles) $)^{[15]}$.
Common side effects of BTX-A injections in the salivary glands of humans are usually minor and temporary such as local hematoma, pain and erythema, mild dysphagia, dry mouth and viscous saliva ${ }^{[16]}$. In rare cases, major complications occur that require hospitalization such as loss of motor head control, aspiration pneumonia and severe dysphagia ${ }^{[17]}$. Animal studies using BTX injection in salivary glands have shown contradictory results. Some have demonstrated minimal histological changes in either parotid or submandibular glands in rats. In a study done by Ellies et al., 2000 ${ }^{[18]}$, the parotid glands injected by BTX-A showed slightly lower nuclear counting than in controls and slight increase in acinar volume. Reduction in size of the submandibular glands without permanent histological changes in the cells with lymphocytic infiltration was observed in another study ${ }^{[11]}$. On the other hand; some authors have demonstrated significant structural and functional changes in the parotid gland of rats ${ }^{[19]}$. Size reduction of acinar cells, fibrosis, ultrastructural changes and apoptosis in acinar and ductal cells accompanied with decreased salivary flow were seen in a study done on rabbit submandibular gland ${ }^{[20]}$.

In the present study, intramasseteric injection technique was used since intra-masseteri BTX injections are not uncommon. They are relatively new means of treating oromandibular dystonia, temporomandibular joint dysfunction and masseter muscle hypertrophy. Enlarged masseters caused by masseter hypertrophy results in square-shaped face, which is found esthetically disagreeable in some Asian countries, therefore increasing demand for masseter reduction ${ }^{[21-23]}$.

Regardless of the numerous studies aiming to reduce the masseter size, BTX injections are not without risk. It has been previously advised that intramasseteric injection of BTX just beneath the zygomatic bone should be avoided since this may impair zygomatic muscles function which result in awkward facial expression especially when smiling $^{[24]}$. Smile asymmetry was reported in some cases of BTX-A injection to treat masseter hypertrophy that might be caused by diffusion to risorius muscle. The authors recommended that smile limitation is a limiting factor that should be noted to patients undergoing BTX therapy before the procedure ${ }^{[25]}$. It has been postulated that when BTX is injected, the toxin might affect adjacent tissues via direct diffusion or distant tissues through neuroaxonal or hematogenous transport ${ }^{[26]}$.

Regarding the effect of intramasseteric injection of BTX on salivary glands, in a study where BTX-A was injected into masseter muscles of volunteers. There were no significant changes in salivary flow rate before and after injection ${ }^{[27]}$. In another study, where BTX-A was injected into the masseter muscles of patients with spastic trismus and masseter hypertonia. There were no significant changes in amount of saliva or saliva frequency score ${ }^{[28]}$. On the contrary, in a later experiment where BTX-A was injected in the masseter muscle of cadavers, xerostomia, diminished and thicker saliva were observed and it has 
been suggested that this was caused by excessive diffusion of the toxin to the parotid gland ${ }^{[29]}$. Therefore due to these variable results in literature, the present research studied the possible effect of intramasseteric injection of BTX-A on remote organs such as submandibular glands of rats.

In the current study, submandibular glands of subgroups IIIA, IIIB and IVA showed cytoplasmic vacuolations in acini. This agrees with Younis et al. 2013 ${ }^{[19]}$ who detected extensive and coarse vacuoles in acinar cells of parotid glands injected with $2 \mathrm{u}$ of BTX-A. They also reported increased endoplasmic reticulum and degenerated mitochondria when glands were examined ultrastructuraly.

The acini of subgroup IVB showed irregular outline which is in accordance with Teymoortash et al., 2007 ${ }^{[12]}$ who reported that acinar shape was slightly elongated when submandibular gland was injected with $5 \mathrm{u}$ of BTX-A.

In addition, acini of subgroup IVB showed areas of complete degeneration. In subgroups IIIB, IVA and IVB, desquamated cells and increased spacing were seen between acini. IDs showed flattened cells and decreased number of nuclei in some areas of subgroup IVB. Degenerative changes could also be observed in other ducts types. This comes to an agreement with Shan et al., $2013^{[20]}$ who reported apoptosis in acinar and ductal cells in rabbits 'submandibular glands injected with $5 \mathrm{U}$ and 10 U of BTX-A.

In the present study, statistical analysis of the diameter of acini was significantly increased in the botox injected subgroups when compared to the control subgroups. Subgroup IVB also showed a significant increase in the diameter when compared to other BTX-A injected subgroups. This agrees with Ellies et al., 2000[18] who reported slight increase in acinar volume of parotid glands after being injected with $2.5 \mathrm{u}$ of BTX-A when compared to the control. On the contrary, a later study documented a decrease in parotid acinar size when injected with $2 \mathrm{u}$ of BTX-A $\mathrm{A}^{[19]}$, however the authors didn't undergo morphometric analysis. In another study, a decrease in the diameter of acini of submandibular and sublingual glands was documented after being injected with BTX-A of a dose $2.5 \mathrm{u}^{[30]}$. Nevertheless, the authors applied the injection for three times throughout the experiment. This might explain differences than the results of the present study.

S100 protein family members are multifunctional proteins that interact with several effector proteins in the cells . They are involved in the regulation of variable cellular processes such as contraction, cell growth and differentiation, transcription, protection from oxidative cell damage, protein phosphorylation and secretion ${ }^{[31]}$.

The presence of $\mathrm{S} 100$ protein was reported in some neurons, glial, and Schwann cells of normal nervous tissues $^{[32]}$. The distribution of $\mathrm{S} 100$ protein in normal salivary glands is contradictory, where it could not be detected in an early study in acini, intercalated ducts, striated ducts or excretory ducts of normal salivary glands. However, it could be detected in myoepithelial cells surrounding acini and intercalated ducts ${ }^{[33]}$. In addition, S 100 protein was detected in myoepithelial cells and occasional ducts of salivary glands ${ }^{[32]}$. Moreover, S100 protein has been detected in some luminal cells of intercalated ducts and in myoepithelial cells ${ }^{[34]}$. Weak staining of the S-100 protein was previously documented in myoepithelial cells, secretory portions, granular convoluted tubules and striated ducts of normal submandibular glands ${ }^{[35]}$.

It has been previously reported that $\mathrm{S} 100$ proteins can be released into extracellular space in response to stimuli or during cell damage. Also they promote responses including neuronal survival and extension, apoptosis, inflammation, chemotaxis and cell proliferation and survival[36,37]. It has been claimed that raised S100 protein levels were also accompanied with chronic inflammation, neural degeneration, atherosclerosis and cancer diseases ${ }^{[38]}$.

In the current study, area percentage of anti-S100 protein was significantly increased in botox injected subgroups when compared to the control. Area percentage was also significantly increased in subgroup IVA when compared to subgroup IIIA. Subgroup IVB also showed a significant increase in the area percentage of anti-S100 protein when compared to other BTX-A injected subgroups. This agrees with the study done by Park et al., $2016^{[39]}$ who examined the effect of $5 \mathrm{u}$ and $10 \mathrm{u}$ of BTX-A injection on the masseter muscle of rats, where expression of S100 protein was increased in the masseter muscle of BTX-A injected groups when compared to the control. The authors postulated the increase in $\mathrm{S} 100$ protein might be due to muscle atrophy or apoptotic stress after injection with BTX-A. They also supposed that the increase in S 100 protein might occur as a mode of protection for myoblasts from apoptosis after injecting BTX-A. Furthermore, it has been postulated that antibodies against S-100 protein can be used as a useful marker for cellular injury in salivary glands after the treatment with two different doses of amitriptyline an antidepressant drug ${ }^{[35]}$.

\section{CONCLUSION}

From the present study, it is concluded that intramasseteric injection with BTX-A was able to induce histological changes in submandibular salivary gland of the ipsilateral side in Albino rats. BTX-A dose and duration following injection are supposed to be important factors affecting histological alterations. Further investigations are recommended to investigate the remote effect of BTX-A with other doses and longer durations.

ABBREVIATIONS
BTX, Botulinum toxins; BTX-A, Botulinum toxin
type A; SNAPs, synaptosomal-associated proteins; Ach,
acetylcholine; H\&E, Hematoxylin and Eosin; SD, standard
deviation; ANOVA, One-way analysis of variance; IDs,
Intercalated ducts; GCTs, Granular convoluted tubules;
SDs, Striated ducts; ED, Excretory ducts.




\section{CONFLICTS OF INTEREST}

There are no conflicts of interest

\section{REFERENCES}

1. Munchau A and Bhatia K P: Regular review: Uses of botulinum toxin injection in medicine today. BMJ. (2000) 320:161-165.

2. Dressler D and Saberi F A: Botulinum Toxin: Mechanisms of Action. Eur Neurol. (2005) 53:3-9.

3. Felber E S: Botulinum Toxin in Primary Care Medicine. Review article.JAOA. (2006) 106(10): 609-614.

4. Laskawi R: The use of botulinum toxin in head and face medicine: an interdisciplinary field. Head Face Med. (2008) 4 : ( 5).

5. Bushara KO: Sialorrhea in amyotrophic lateral sclerosis: a hypothesis of a new treatmentbotulinum toxin A injections of the parotid glands. Med Hypotheses. (1997) 48: 337-339.

6. Ellies M, Gottstein U, Rohrbach-Volland $\mathrm{S}$, Arglebe $\mathrm{C}$ and Laskawi R: Reduction of salivary flow with botulinum toxin: extended report on 33 patients with drooling, salivary fistulas, and sialadenitis. The Laryngoscope. (2004) 114: 18561860 .

7. Turk-Gonzales M and Odderson I R:. Quantitative reduction of saliva production with botulinum toxin type $\mathrm{B}$ injection into the salivary glands. Neurorehabilitation and Neural Repair. (2005) 19: 58-61.

8. Lagalla G, Millevolte M, Capecci M, Provinciali $\mathrm{L}$ and Ceravolo MG: Long-lasting benefits of botulinum toxin type B in Parkinson's diseaserelated drooling. J Neurol. (2009) 256: 563-567.

9. Intiso D: Therapeutic Use of Botulinum Toxin in Neurorehabilitation. Journal of Toxicology. (2012) Volume 2012, Article ID 802893, 12 pages.

10. National Research Council (US) Committee for the Update of the Guide for the Care and Use of Laboratory Animals: Guide for the Care and Use of Laboratory Animals, 8th ed. National Academy Press, Washington. (2011) pp. 41-196.

11. Coskun BU, Savk H, Cicek ED, Basak T, Basak M and Dadas B: Histopathological and radiological investigations of the influence of botulinum toxin on the submandibular gland of the rat. Eur Arch Otorhinolaryngol. (2007) 264: 783-787.

12. Teymoortash A, Sommer F, Mandic R, Schulz S, Bette M, Aumüller G and Werner JA: Intraglandular application of Botulinum toxin leads to structural and functional changes in rat acinar cells. $\mathrm{Br} \mathrm{J}$ Pharmacol. (2007) 152:161- 167.
13. Bancroft J D, Suvarna K and Layton C. Bancroft's Theory and Practice of Histological Techniques (7th ed.) Churchill Livingstone : Elsevier (2013) pp:173-186.

14. Al-Fayez M A, Atteya M, Mohamed RA, Ahmed AM, Alroalle AH, Khalil MS, Al-Ahmed M and Payne A: Adrenal medulla of AS/AGU rats: a histological and immunohistochemical study. Folia Morphol. (2017) 76(1): 28-37.

15. Nayyar P, Kumar P, Nayyar PV and Singh A: Botox: Broadening the horizon of dentistry. Journal of Clinical and Diagnostic Research. (2014) 8(12): 25-29.

16. Jongerius PH, Rotteveel JJ, Van Limbeek J, Gabreëls F JM, van Hulst K and Van den Hoogen F JA: Botulinum toxin effect on salivary flow rate in children with cerebral palsy. Neurology. (2004) 63: $1371-1375$.

17. Chan KH, Liang C, Wilson P, Higgins D and Allen GC : Long-term safety and efficacy data on botulinum toxin type A: an injection for sialorrhea. JAMA Otolaryngol Head Neck Surg. (2013) 139(2): 134-138

18. Ellies M, Laskawi R, Tormahlen G and GÖTZ $\mathrm{W}$ : The effect of local injection of botulinum toxin A on the parotid gland of the rat: an immunohistochemical and morphometric study. Journal of Oral and Maxillofacial Surgery. (2000) 58:1251-1256.

19. Younis RE, Abouelkheir MT, Mourad MI and Elnahas W: The ultrastructural changes of the parotid gland of rats after intraglandular injection of botulinum toxin A. Annals of Oral \& Maxillofacial Surgery. (2013) 1(4): 38.

20. Shan XF, Xu H, Cai ZG, Wu LL and Yu GY: Botulinum toxin A inhibits salivary secretion of rabbit submandibular gland. International Journal of Oral Science. (2013) 5: 217-223.

21. Kim NH, Chung JH, Park RH and Park JB: The Use of Botulinum Toxin Type A in Aesthetic Mandibular Contouring. Plast Reconstr Surg. (2005) 115: 919-930.

22. Chang CS, Bergeron L, Yu CC, Chen PK and Chen YR: Mandible changes evaluated by computed tomography following Botulinum toxin A injections in square-faced patients. Aesthetic Plast Surg. (2011) 35:452-455.

23. Liu ZJ, Rafferty KL, Ye W and Herring SW: Differential response of pig masseter to botulinum neurotoxin serotypes A and B. Muscle Nerve. (2015) 52(1): 88-93. 
24. Ascher B, Talarico S, Cassuto D, Escobar S, Hexsel D, Jae' n P, Monheit GD, Rzany B amd Viel M:. International consensus recommendations on the aesthetic usage of botulinum toxin type A (SpeywoodUnit) - part II: wrinkles on the middle and lower face, neck and chest. JEADV. (2010) 24 : $1285-1295$.

25. Klein FH, Brenner FM, Sato MS, Robert FM and Helmer KA: An Bras Dermatol. (2014) 89(5): 878-884.

26. Kuwahara $\mathrm{H}$ and Ogawa R: Using a Vibration Device to Ease Pain during Facial Needling and Injection. Eplasty. (2016) 16:65-72.

27. Kwon JS, Kim ST, Jeon YM and Choi JH: Effect of botulinum toxin type A injection into human masseter muscle on stimulated parotid saliva flow rate. Int J Oral Maxillofac Surg. (2009) 38: 316-320.

28. Fietzek UM, Kossmehl P, Barthels A, Ebersbach $\mathrm{G}$, Zynda B and Wissel J: Botulinum toxin B increases mouth opening in patients with spastic trismus. European Journal of Neurology. (2009) 16: 1299-1304.

29. $\mathrm{Hu} \mathrm{KS}$, Kim ST, Hur MS, Park J H, Song WC, Koh KS and Kim HJ: Topography of the masseter muscle in relation to treatment with botulinum toxin type A. Oral Surgery, Oral Medicine, Oral Pathology, Oral Radiology and Endodontology. (2010) 110: 167-171.

30. Regueira LS, Baratella-Evêncio L, de Oliveira JB, da Silva PSOC, Valença GAL, Conceição JCP and Perez DED: Effects of chronic treatment with botulinum toxin type A in salivary glands of rats: Histological and immunohistochemical analyses. J Oral Pathol Med. (2019) 48: 728-734.
31. Santamaria-Kisiel L, Rintala-Dempsey AC and Shaw GS: Calcium-dependent and independent interactions of the $\mathrm{S} 100$ protein family. Biochem J. (2006) 396: 201-214.

32. Khan HJ, Marks A, Thom H and Baumal R: Role of Antibody to S100 Protein in Diagnostic Pathology. Am J Clin Pathol. (1983) 79: 341-347.

33. Hara K, Ito M, Takeuchi J, Iijima S, Endo T and Hidaka H: . Distribution of S-100b protein in normal salivary glands and salivary gland tumors. Virchows Arch A Pathol Anat Histopathol. (1983) 401: 237-249.

34. Zhu S, Schuerch C and Hunt J: Review and Updates of Immunohistochemistry in Selected Salivary Gland and Head and Neck Tumors. Arch Pathol Lab Med. (2015) 139: 55-66.

35. Elsharkawy GEZ and Alhazzazi TY: The Effect of the Commonly Used Antidepressant Drug Amitriptyline (TCAs) on the Salivary Glands. J Dent Oral Disord Ther. (2016) 4(4): 1-5.

36. Donato R: RAGE: a single receptor for several ligands and different cellular responses: the case of certain S100 proteins. Curr Mol Med. (2007) 7:711-724.

37. Leclerc E, Fritz G, Vetter SW and Heizmann CW: Binding of S100 proteins to RAGE: an update. Biochim Biophys Acta. (2009) 1793: 993-1007.

38. Pietzsch J: S100 proteins in health and disease. Amino Acids. (2011) 41:755-760.

39. Park YW, Kim SG and Jo YY: S100 and p65 expression are increased in the masseter muscle after botulinum toxin-A injection. Maxillofac Plast Reconstr Surg. (2016) 38: 33. 


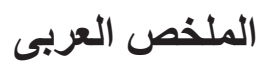

\title{
تأثير حقن توكسين البوتولينوم النوع أ داخل العضلة الماضغة على الغدة اللعابية تحت الفكية بنفس الجانب في الفئران البيضاء
}

\author{
صفاء إسماعيل حسين \\ قسم بيولوجيا الفـم ـ كلية طب الأسنان - جامعة عين شمس ـ القاهرة ـ مصر
}

الخلفية: يستخدم توكسين البوتولينوم في التحكم في انقباضات العضلاتُ زيادة التعرق و زيادة افراز اللعاب. و لقد تم تسجيل بعض الاثار الجانبية البسيطة مثل التجمع الدموي الموضعي' الالم' جفاف الفمو اللعاب اللزج. و بالر غم من ذلك فقد سجت بعض المضاعفات الجسيمة مثل فقدان التحكم في حركة الر اس و الالتهاب الرئوى. أظهرت بعض التجارب على الحيو انات بعض التغير ات الهستولوجية البسيطة بينما اوضح بعض العلماء وجود تغير ات وظيفية في الغدد النكفية للفئر ان و تحت الفكية في الار انب بعد حقنهم بتوكسن البوتولينوم النوع أ.

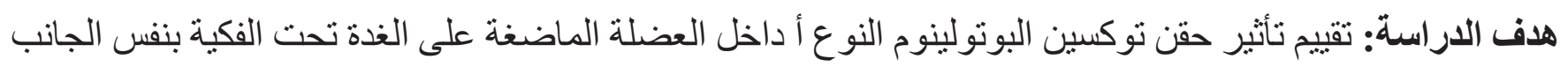
في الفئر ان البيضاء. طرق و مواد البحث: قسمت ستة و خمسين فار ابيض بالغ ذكر على اربعة مجموعات. و تم حقن فئران المجموعة

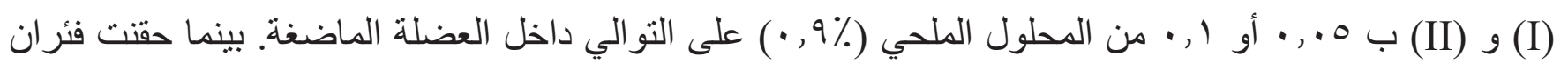
المجمو عتين (III) و (IV) ب r, o وحدة او 0 وحدات من توكسين البوتولينوم النوع أ على التو الي داخل العضلة الماضغة. قسمت كل مجمو عة فيما بعد الى مجمو عتين تبعا لميعاد التضحية بالفئر ان و الذى كان عند ثلاثة أو اربعة

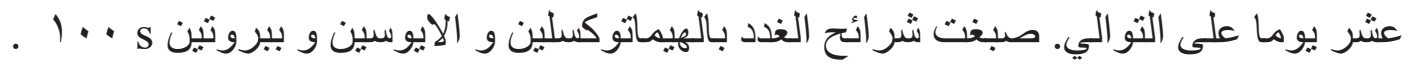
النتائج: أظهرت عنيبات المجمو عتين (III) و (IV) فر اغات في السيتوبلازم كما اظهرت عنيبات المجموعة (IV) عند اربعة عشر يوما شكلا غير منتظماو مناطق ذات تحلل كامل. كما اظهرت القنو ات للمجمو عتين علامات للتحلل. باستخدام الصبغة الهستوكيميائية المناعية اظهرت المجمو عنين (III) و (IV) زيادة في المساحة الايجابية بالمقارنة بالمجمو عات الضابطة. اظهر التحليل الاحصائي لقطر العنيبات و المساحة الايجابية لصبغة بروتين s · ، ا زيادة بالغة

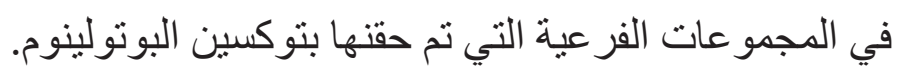
الخلاصة: كان حقن توكسين البوتولينوم النوع أ داخل العضلة الماضغة قادر العلى احداث تغير ات هستولوجية في الغدة تحت الفكية بنفس الجانب. و قد لوحظ أن جر عة توكسين البوتولينوم و المدة التي تلي الحقن عاملان مؤثران في حدوث التغير ات الهستولوجية لذلك يوصي بالمزيد من الأبحاث لدراسة التأثير البعيد لتوكسين البوتولينوم باستخدام جرعات أخري و مدد أطول. 